\title{
The Implementation of Classroom Observation Supervision In Senior High School
}

\author{
Dewi Ramadhani Astyowati, Karwanto \\ Universitas Negeri Surabaya \\ Surabaya, Indonesia \\ dr.astyowati@gmail.com
}

\begin{abstract}
The purpose of this study is to describe and analyze: (1) the preparation for supervision of classroom observations, (2) the process of supervision of classroom observations, 3 ) the reciprocal meetings by principals, and (4) the implementation of classroom observation supervision. This study used a qualitative approach with case study design. Data collection techniques were done in form of interview, observation and documentation techniques. Data analysis in this study employed data reduction, data presentation and conclusion drawing. Checking the validity of the data was also performed by using credibility, using data triangulation.
\end{abstract}

Keywords-teacher professional improvement; classroom observation supervision

\section{INTRODUCTION}

Education is a plan to create an atmosphere of learning and learning process for learners actively to develop their potential. In addition, education serves students to have self-control, personality, intelligence, noble character, as well as skills which are needed in society. One of the goals of education is to create qualified and characterized human beings so as to have a broad view of the future to achieve a goal that is expected and able to adapt quickly and precisely in various environments, because education itself motivates us to be better in all aspects of life.

The achievement of educational goals depends on the wisdom and leadership skills of the principal. The principal is a functional teacher who is in charge of leading a school in coordinating the learning process together in order to achieve the learning objectives at the school-led level.

Refer to [1] who shows that principal must utilize all school's personnel effectively and efficiently so that the purpose of education in the school can be achieved optimally. Teachers play an important role in improving and developing the quality of education. Qualified teachers are expected to improve the quality of learning and produce quality output as well. This is because teachers have a high teaching ability, which are able to optimize and analyze or use the components of education such as teaching media, curriculum and others so that the process of learning will be better.

Teachers are the most important component of the education system in schools because they are the principal actors, activators, spearheads and are responsible in directing the success of the students to achieve the learning objectives. Therefore, the success of teachers is determined by their ability to master the competence of teaching skills and commitment in performing their duties as a professional teacher.

Teachers are the determinants factor of the success of education through the learning process in the classroom. As stated in [2] that teachers are meaningful as professional educators with the main task of educating, teaching, guiding, directing, training, assessing, and evaluating learners on formal education. The main task will be effective if the teacher has a certain professional performance reflected from their competence, interaction and communication. They are also expected to conduct guidance and counseling, and should be able to earn skills that meet the standards of quality or ethical norms.

As a professional competence teacher, there are such abilities that teachers must have in planning the learning process. Teachers have the task to manage the learning process and to achieve learning objectives. For that reason, teachers are required to master the materials. [2] Shows that teacher should always update and master the presented subject matter. Preparation of the material is endeavored by seeking information through various sources such as reading the latest books, accessing from the internet, always keeping up with the latest developments and taking a serious attention on the progress of the presented material [3].

Sahertian explains that "the professional competence of teachers is the mastery of academic subjects taught" which is integrated with his teaching skills as their level of academic authority [4]. The ability that teachers should have in the learning process can be observed from the professional aspect such as: (1) mastering the materials, structure, concepts, and scientific thinking patterns that support the subjects being taught; (2) mastering the competency standard and basic competency of the subjects; (3) developing creative subject matter creatively; (4) developing professionalism in a sustainable manner by taking reflective action.

The quality of professional teachers has a very important role because they are directly in charge of teaching and learning process. In conducting a good teaching and learning process, it requires professional skills, namely the ability to plan the lesson, manage teaching and learning activities, implement learning and assess the progress of teaching and learning process. Teachers in carrying out their duties must also be able to guide, motivate, educate, direct, train, assess and evaluate learners. 
Making teachers as professionals is necessary to provide continuous and continuous guidance. To make the teacher as a workforce, there needs to be considered, appreciated and recognized professionally. Academic supervision is one of the duties and responsibilities of the principal, senior teachers and supervisory teams of the Office of Education in fostering teachers through supervisory functions. Supervision is indeed an activity of doing coaching, a guidance to help teachers developing their ability to manage the learning process to achieve learning objectives. The main task of supervisors as supervisors or academic supervisors is to evaluate and monitor the implementation in the learning process, while managerial supervisor is the main task of supervisors who emphasize more on aspects of school management.

Supervision activities are complement in the management functions of schools, they function as the evaluation and monitoring of all learning activities in achieving learning objectives. Supervision has a role to optimize the responsibilities of all programs. Supervision is concerned with all research efforts aimed at all aspects that will be critical success factors. Sagala suggests that "supervision is a process used by school personnel who are responsible for aspects of school's goals and is directly dependent on personnel of the school's goals [5].

The purpose of this study is to find out, describe and analyze: (1) the preparation of supervision of classroom observations by the principal at GIKI 1 Surabaya High School, (2) the process of supervision of classroom observations by the principal at GIKI 1 Surabaya High School, (3) the reciprocal meeting by the Surabaya GIKI 1 High School principal, and (4) the implementation of classroom observation supervision to improve professional teachers' skills at GIKI 1 Surabaya High School.

\section{METHOD}

The focus of this study was to find out professional teachers at GIKI 1 Surabaya High School by looking at the activities of teacher in term of their professional improvement efforts and supervision of classroom observations conducted by the principal. This study used a qualitative approach with case study design. Data collection techniques were: (1) interview techniques conducted to several informants including the head of the GIKI 1 SMA foundation, GIKI 1 SMA school principals, GIKI high school teachers and students, (2) observation, and (3) documentation.

The research design that is carried out in broad outline can be divided into several stages, namely: (1) the preparatory phase. At the preparation stage, there were the collection of data or information and materials that are in accordance with the focus of the problem in this study. (2) The implementation phase. At the implementation stage there were such actions like conducting observations, surveying, to collecting data in the field. (3) The final stage. At this stage researchers conducted data analysis, drew conclusions, and prepared research reports.

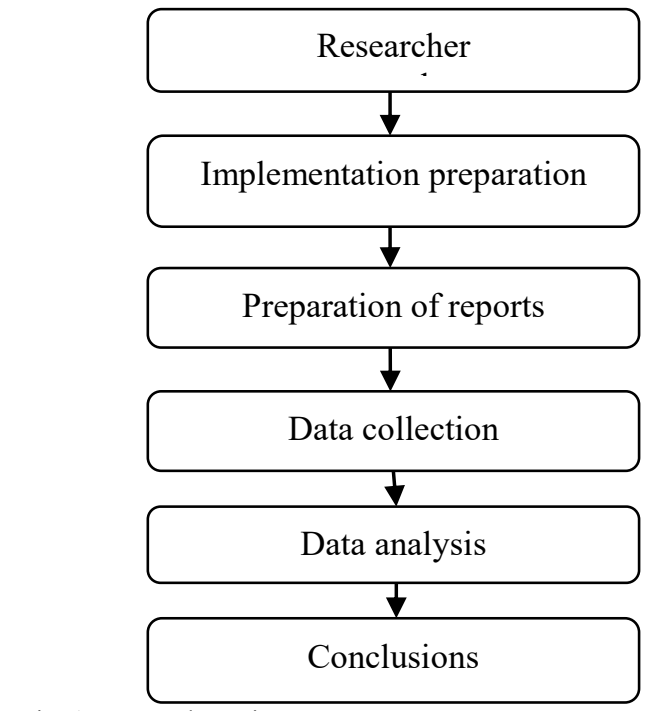

Fig. 1. Research Design

In detail, the design of this study started from observations and brief interviews with the Principal of GIKI 1 Surabaya High School in the efforts to understand the conditions of the location as the background of the study and as pre-research activities. Furthermore, the stage of preparing equipment or material for research purposes was done. It was about preparing a thesis or research design that is used as a temporary reference as a research process that was carried out and was disseminated before the testing team.

The next step was to submit a research letter to the involved parties to fulfill the administrative requirements of a study. After the whole process had completed, researchers need to prepare themselves and paid attention to ethics before going into the field to collect relevant data in accordance with the research objectives.

After collecting data, the data analysis process was carried out. To strengthen the analysis, the researcher compared the data obtained from the field with the relevant theory. The final stage of this research process was drawing conclusions and preparing a complete research report for later testing. Fig. 1 shows the entire process above.

\section{RESULTS AND DISCUSSION}

\section{A. Preparation of Classroom Observation Supervision}

Based on the research findings, it is found (1) the determination of the schedule of supervision implementation, (2) the process of supervision, making instrument, monitoring, and implementation formats of supervision, (3) the process of making supervision in the form of data and records, that contain teachers' identity, identity supervision, implementation and components of supervision, (4) the foundation of supervision in one year and a disciplinary report in carrying out the task. The characteristics of the supervision preparation procedure for classroom observations conducted by the GIKI 1 Surabaya high school basically based on the theory of [6], stating that supervision preparation has steps to improve teachers' teaching skills that include the teaching material and the tools used as a result of supervision. Moreover, it includes 
supervised teachers, which classroom, and how to determine time. The same thing is in accordance with [7], saying that the steps that must be in regular order in preparing the supervision instrument. They are stated as follows: (1) formulating the objectives to be achieved with the supervision instruments, (2) creating a grid containing details variables and types of supervision instruments that will be used to measure the part of the variable in question, (3) making items of the supervision instrument, and (4) editing the supervision instrument.

This is similar with [8], who state that the aspects of classroom observation supervision preparation include: annual program, semester program, syllabus, Lesson Plan (RPP), daily agenda, list of value, Maximum completeness criteria (KKM), educational calendar, meeting schedule, and student attendance. Also in [9], preparation of classroom observation supervision include distributing supervision schedules.

The opinion of the ideal researcher related to the preparation of supervision of class observations are stated as follows (1) the implementation of class supervision schedules in accordance with the theory of the speech, (2) the orderly administration and format of performance appraisal that has been carried out, (3) the supervision by the foundation that needs to be increased from one implementation in one year to two or three times a year. These are done to improve teachers' supervision, discipline and professionalism.

\section{B. The Process of Supervision of Classroom Observation}

Based on the research findings, it is found that (1) the principal or senior teacher as a supervisor assesses the learning process objectively, (2) the supervision of classroom observation was carried out in a quiet classroom atmosphere, and it was performed while teaching performance, (3) the supervisor observed the teacher and student responses when it was in a learning environment, (4) the supervisor only monitored and was not involved with the ongoing learning process. Characteristics of supervision procedures for classroom observation conducted by the headmaster of GIKI 1 Surabaya High School are basically in accordance with the theory of [6]. It says that the steps for teachers to understand the aspects of teaching is by observing the principal in teaching the teacher in front class, observed class response and students. The same thing is stated by [4], that the process of supervision of classroom observation are in term of: (1) supervisors with the teacher the direct classroom observation where the learning process was taking place, (2) the teacher explains to students about the purpose of supervisors in the classroom, (3) the teacher invites the supervisor to occupy the seat provided, (4) the teacher starts to carry out activities referring to the lesson plan (RPP) that has been made, (5) the supervisor observes the teacher's performance based on the agreed observation format, and (6) after the teacher finishes to carry out a whole set of learning activities, the supervisor leaves the classroom and moves to teacher's room or coaching room.

This is also consistent with [10], saying that the process of supervising classroom observations consists of 10 aspects namely writing a daily learning plan, determining induction, presenting and developing lesson, questioning techniques, student participation, consolidation, training and student assignments, evaluating exercises and assignments, closing lessons, and class control. This is similar with [8] who state that the aspects of the process of supervision of classroom observation are ranging from opening activities, core activities, and evaluating the learning where this aspect is the most dominant in supervision. It is also in [9], showed that: (1) the process of supervision of classroom observation is based on subjects supervised by principals. Supervising teachers is done to improve learning while supervisors supervise principals in managerial and academic supervision fields for teachers, (2) the school principal is more flexible while the school supervisor is scheduled, (3) principals observe teaching and learning activities while school supervisors only supervise administration and teaching preparation, (4) supervision the school principal was followed up with a school activity program. For example the process can be followed by holding a K13 workshop after concluding that the results of teacher supervision were still lack in term of mastering the K13, while the school supervisor has no follow-up, and (5) the teacher feels more comfortable in the supervision of the principal than in the supervision of the school supervisor, because the teacher is closer in case of personal relationship with the principal.

According to the ideal researcher's opinion related to the supervision process of class observation, it is found as follows: (1) a supervisor in the classroom supervision observation process has carried out by the principal in accordance with the theory, (2) the supervisor's assessment was still lack in finding a natural atmosphere in the learning process, and (3) supervisor did not only records or recorded feedback between students and teachers, but they need also to record the solutions that teachers do when students have difficulty to understand the topic given.

\section{Reciprocal Meeting of Classroom Observation Supervision}

Based on the findings of the study, it is found that (1) the results of the discussion and evaluation between the supervisor and the teacher were very significant in improving student achievement (2) improving soft skills through training, courses, seminars and comparative studies can improve teachers' performance, (3) the results of the supervision implementation provided positive reinforcement and was ended with a followup agreement, (4) the teacher got supervision results to become a teacher with professional improvement record. The characteristics of the reciprocal meeting procedures carried out by the GIKI 1 Surabaya high school principals are basically based on [6], who stated that reciprocal meetings provide reinforcement to teachers. This strengthening is very significant to encourage teachers to improve their skills $o$ ability. The same thing is described by [11], stating that reversal meetings in classroom observation need to be provided to enrich reinforcement, as well as to improve the round-trip meeting of classroom observation supervision. This supervision will also provide positive reinforcement and negative reinforcement. Positive reinforcement is in the form of giving praise or a satisfied smile while negative reinforcement can be in term of reducing the task for the teacher who has been able to improve himself.

This is also consistent with [12], who state that the supervision at classroom observations analyzes the 
effectiveness of the learning that has been carried out. At this meeting, the principals behaved as intimately as possible with the teacher in delivering the observations according to the learning that has been done. In this discussion the school principal and the teacher discussed the agreed-upon matters relating to how successful the learning achievement was. Furthermore, this discussion will make a new agreement after the principal provides input to the teacher regarding the obstacles experienced by the teacher.

Also, according to [13], a meeting of supervising classroom observations involves (1) attending meetings or meetings of professional organizations, (2) discussing the objectives and philosophy of education with teachers, (3) holding group meetings to discuss common problems, (4) conducting visitation or class visit classes, (5) holding individual meetings with teachers about the problems they propose, and (6) discussing teaching methods with teachers.

Likewise in [14], the meeting stage reverses supervision of classroom observations. It is done after analysis conversations between supervisors and teachers and discussions on how to improve them. According to the ideal researcher's opinion related to the reversal supervision of classroom observation, it is stated as in the following: (1) supervision results are not only discussed with the teacher but also they can be widened in the form of seminars like in case of inviting competent parties in the specified topic, (2) improving soft skills, training, courses and seminars are not only conducted by supervised teachers, but also all teachers in the same class level, (3) supervision results should be used as a program to improve the classroom learning process and improve the academic of each subject, and (4) the final supervision results that are handed over to teachers will spur teacher performance and professionalism.

\section{Implementation of Class Observation Supervision}

Professional improvement of teachers is done so that teachers can master and be able to expand their competencies properly in accordance with the scientific fields they bear so that reliable and professional teaching staff will be gained. In other words, improvements need to be made so that the competencies and abilities of the teacher and their beneficial nature for students need to be developed.

Based on the findings of the researchers, it was found that the improvement needs to be carried out so that the formation of achievements towards the students in GIKI 1 High School could be well formed. Achievement of the goal of improvement, specifically to shape student achievement, needs strategies. [15] Shows that the achievement of the objectives requires the ability of employees to estimate and anticipate circumstances that can have an impact on the organization. This is also in line with [16], who said that one of several internal factors that influence improvement is a strategy to achieve special competencies, so that the teacher is truly able to demonstrate the achievement of optimal professional abilities. With this strategic position, of course achieving goals becomes very important to be concerned. In the ideal of researchers' opinion related to the determination of teacher professional improvement that determining teacher professional improvement needs in addition to bear the goal of shaping students' achievement.
Research findings indicate that the goal in an effort to improve teacher professional in GIKI 1 Surabaya High School is improving teacher skills, such as teaching methods, class mastery, and so on. This is in line with [16] that improvement is a process that has goals to be achieved by setting targets. The key success of individuals or organizations in achieving these targets or goals is performance. This is also in line with [17] who says that improvement is a process of improving teacher professional competence such as mastery of learning material widely and in depth. It includes mastery of curriculum material in school subjects and scientific substance that overshadows the material and mastery of the structure and scientific methodology. According to the ideal researcher's opinion related to the teacher's professional improvement goals that in improving teacher's skills, schools are in desperate need of an improvement program for teachers in achieving organizational goals and objectives.

Based on the research findings, the implementation of the school improvement program content could not be determined definitively. The improvement was carried out in accordance with the needs or in accordance with the situation and conditions, either according to the urgency or unwanted improvement. It is shown in 2013 curriculum in term of workshops, trainings, or meeting. This is in accordance with [18]. It says that the purpose of training or workshops is held so that the teacher has good abilities who are not just "the teachers who stand teaching in class" but the teacher who also acts as a counselor, instructor in the workshop activities. According to the ideal researchers' opinion related to the implementation of the program content enhancement that the scope and material used in the training, they have been adjusted according to the needs of the organization.

The findings of the study showed that the principles of learning were used in efforts to improve teachers. This is evident in the material or concept of improvement used by schools that are adjusted by holding workshops with the aim that teachers can understand or deepen their abilities and competencies. [19] Shows that the principle of relevance of learning will increase if the learning material is in accordance with the conditions of learning in the maximum class. In the ideal opinion of researchers related to the principle of relevance of learning that the material provided in the process of improvement is highly considered and is adjusted to the needs of the teacher's own improvement.

Based on the findings, the assessment of the teacher's professional implementation can be done through supervision of classroom observations. In connection with this, improvements are made to improve the quality and achievement of schools both teacher quality and student quality. In accordance with [20], classroom observation supervision techniques can be used to improve teacher skills such as discussion supervision techniques, supervision techniques for school visits, scientific meeting supervision techniques, and informal meeting supervision techniques. This is in line with [21], who states that through supervision of classroom observations, the aim of improving the quality and achievement of the school both the quality of teachers and students can be increased. In the ideal researchers' opinion related to the assessment of the teacher's professional 
implementation that the learning process must be completed not only to fulfill the curriculum, it is found that (1) the teacher's professional assessment is not only based on lesson plan (RPP), but also considers interactive learning processes as well as student achievement, and (2) the performance improvement is directly proportional to teacher as professionals.

The findings of showed that the effect of increasing teacher professionalism can be increased through the performance of teachers in school. Good teacher performance is shown by how the way they teach. In line with [22], one of the most effective and efficient vehicles is usually used for teacher professional improvement. It is seen through the teacher's performance in the way they teach, the teacher's abilities, and teacher competence. According to the ideal researcher's opinion related to the influence of the teacher's professional improvement, the improvement of subject matter in the topic of discussion was carried out with the right learning method, comfortable, fun and contextual.

\section{CONCLUSION}

Based on the results that has been described previously, the conclusions can be drawn as follows: (1) the classroom observation supervision preparations conducted at GIKI 1 Surabaya High School include determining which teacher will be supervised, which material to be taught, in which classroom, which tools are used to record the supervision results, and how to determine the time. It was done in notified beforehand, where supervisors came suddenly, or only was notified of the arrival month; (2) the supervision process for classroom observations conducted at GIKI 1 Surabaya High School include the attitude of the supervisor, how to observe the teacher, things observed, how to record data, and how to end the supervision process; (3) the reciprocal meeting of classroom observation supervision conducted at GIKI 1 Surabaya High School was not needed because the teacher's work procedures were good. It was continued with other supervision techniques, continued with the same supervision technique. It is because most of the teacher's work procedures had not been well, and followed by clinical supervision techniques, because the teacher is lack in understanding the concepts; and (4) implementation of classroom observation supervision conducted in GIKI 1 Surabaya High School are the activities of training or workshop activities and meetings or seminars.

\section{REFERENCES}

[1] B. Suryosubroto, Manajemen pendidikan di sekolah. Rineka Cipta, 2004.

[2] S. Danim, Inovasi pendidikan dalam upaya peningkatan profesionalisme tenaga kependidikan. Pustaka Setia, 2002.

[3] J. S. Badudu and S. M. Zain, "Kamus Bahasa Indonesia Umum." Cet ke4 Jakarta: Pustaka Sinar Harapan, 2001.

[4] P. A. Sahertian, Konsep dasar \& teknik supervisi pendidikan: dalam rangka pengembangan sumber daya manusia. Penerbit Rineka Cipta, 2000 .

[5] S. Sagala, "Supervisi Pembelajaran dalam profesi pendidikan," Bandung Alf., 2010.

[6] M. Pidarta, Supervisi Pendidikan Kontekstual. Rineka Cipta, 2009.

[7] S. Arikunto and L. Yuliana, "Manajemen pendidikan," Yogyakarta: Aditya Media, 2008.

[8] M. Messi, W. A. Sari, and M. Murniyati, "Pelaksanaan Supervisi Akademik Pengawas Sekolah sebagai Upaya Peningkatan Profesionalisme Guru," JMKSP (Jurnal Manajemen, Kepemimpinan, dan Supervisi Pendidikan), vol. 3, no. 1, 2018.

[9] N. Nurfatah and N. Rahmad, "Pelaksanaan Supervisi oleh Kepala Sekolah dan Pengawas Sekolah," JMKSP (Jurnal Manajemen, Kepemimpinan, dan Supervisi Pendidikan), vol. 3, no. 1, 2018.

[10] A. Veloo, M. M. A. Komuji, and R. Khalid, "The effects of clinical supervision on the teaching performance of secondary school teachers," Procedia-Social Behav. Sci., vol. 93, pp. 35-39, 2013.

[11] N. Purwanto, “Administrasi dan Supervisi Pendidikan. 2010," Bandung: Remaja Rosdakarya.

[12] F. K. Sarfo and B. Cudjoe, "Supervisors' Knowledge and Use of Clinical Supervision to Promote Teacher Performance in basic schools," Int. J. Educ. Res., vol. 4, no. 1, 2016.

[13] M. Ali, "Supervisi Administrasi dalam Pendidikan," J. Hikmah, vol. 14, no. 1, pp. 21-27, 2017.

[14] Musrifah, "Supervisi Klinis Sekolah Madrasah Terhadap Kinerja Profesional Guru di Madrasah Tsanawiyah Negeri Nusawungu Cilacap," J. Manaj. Pendidik. Islam, vol. 3, no. 1, 2017.

[15] S. Notoatmodjo, "Pendidikan dan perilaku kesehatan." Jakarta: Rineka Cipta, 2003.

[16] M. Sudarma, Profesi guru: dipuji, dikritisi, dan dicaci. PT Rajagrafindo Persada, 2013.

[17] L. Utami, "Pengembangan Kompetensi Profesional Guru Melalui Collaborative Study Group (CSG)," Pros. Ilmu Pendidik., vol. 1, no. 2, 2016.

[18] M. Samani, Profesional Pendidikan. Surabaya: Unesa University Press, 2012.

[19] M. J. Wairimu, “Teachers' Perception on Classroom Observation and Checking of Pupils' Exercise Books by Head Teachers on Performance of Duty in Primary Schools in Nakuru North District, Kenya," J. Educ. Soc. Policy, vol. 3, no. 3, 2016.

[20] I. Bafadal, Supervisi Pengajaran Teori dan Aplikasinya dalam Membina Profesi Guru. Jakarta: Bumi Aksara, 2008.

[21] M. de N. C. T. Coimbra, "Supervision and Evaluation: Teachers' Perspectives," Int. J. Humanit. Soc. Sci., vol. 3, no. 5, pp. 65-71, 2013.

[22] M. Idris, "The Impact of Supervision, Motivation and Work Ethic on Teachers' Professional Competence: A Case Study of Private Islamic High School Teachers," Int. J. Hum. Resour. Stud., vol. 6, no. 1, pp. 147-158, 2016. 